\title{
Reflections on the Enduring Relevance of Religion and Nationalism in the Survival of Modern Nation-States
}

\author{
By Michael I. Magcamit*
}

\begin{abstract}
This paper reflects on the enduring relevance of religion and nationalism in the survival of modern nation-states. Rather than rejecting these overlooked elements of international relations, I develop a framework that puts these nonrational, nonmaterial cultural sources at the center of the analysis to explain why and how they are relevant to the continued persistence of modern nation-states. The three-track framework introduced here generates conceptual apparatuses that help us understand the processes and dynamics involved, namely: ethnoreligious nationalism, securitized minorities, and sacralized security superstructures. Applying the framework to Southeast Asia, I demonstrate why ethnicized religion and nationalism remain vital to the imagination of contemporary nation-states; and how they are crucial to the construction of structural institutions designed to preserve the conceptual cohesion and material integrity of these units. I argue that the endurance and survival of modern nationstates is strongly attributable to the underlying material security superstructures which are both the outcomes and drivers of interweaving nonmaterial ethnoreligious and nationalist substructures. Drawing on the insights from my theoretical and empirical analyses and evidences from my field research, I conclude that the continuity of modern nation-states has been underwritten by the cultivation of ethnoreligious nationalism, securitization of the 'threat' of othered minorities, and sacralization of security superstructures.
\end{abstract}

Keywords: nation-state, security, religion, nationalism, ethnoreligious conflicts, Myanmar

${ }^{*}$ Michael I. Magcamit, PhD

Marie Skłodowska-Curie Fellow

School of Politics and International Relations

Queen Mary University of London

Address: Room 2.24 Arts One Building

Mile End Rd, Bethnal Green, London E1 4NS

Emails: m.magcamit@qmul.ac.uk / mim49@uclive.ac.nz

Tel No.: +44 07903-389216

Website: www.magcamit.com 


\section{Reflections on the Enduring Relevance of Religion and Nationalism in the Survival of Modern Nation-States}

\section{Introduction}

The growing religious fundamentalism, ethnic factionalism, and nationalist impulses being witnessed today are exposing the limits of scholarly works built around the assumption of progressively modernizing and secularizing nation-states and the inaccuracy of their findings. Some of the most recent examples of these best-selling books include Daron Acemoglu and James Robinson's Why Nations Fail which argued that man-made political and economic institutions underlay both successes and failures of nations across the world. According to the authors, 'nations fail today because their extractive economic institutions do not create the incentives needed for people to save, invest, and innovate. ${ }^{\prime 1}$ Simply put, nations are supposed to fail when their economies fail. Meanwhile, in the highly controversial The End of History and the Last Man, Francis Fukuyama boldly explained why 'it matters very little what strange thoughts occur to people in Albania or Burkina Faso,' since the end point of mankind's ideological evolution and the universalization of Western liberal democracy would be the final form of human government. ${ }^{2}$

In a similar fashion, Kenichi Ohmae's The End of the Nation-State compared nation-states to 'dinosaurs waiting to die' due to their inability to cope with rapidly changing international economic circumstances and opportunities brought about by globalization. ${ }^{3}$ Even Nobel Prize winner Joseph Stiglitz could not seem to escape from the shackles of the classic theory of modernity as evidenced by his Globalization and its Discontents, in which defended the process of globalization from a global backlash by shifting the blame on the corrupt management of powerful international institutions. ${ }^{4}$ Finally, Thomas Freidman neatly summed up the modernistsecularist dream in The World Is Flat when he claimed that globalization had 'flattened' the world - by binding people, markets, and countries closer than ever - and made national borders

\footnotetext{
Acemoglu and Robinson 2012, p. 372.

Fukuyama 1989.

Ohmae 1995.

“ Stiglitz 20002.
} 
remnants of a bygone era. ${ }^{5}$

Contextualizing nation-states in narrow politico-economic terms while framing national struggles as simple matters of 'institutions, institutions, institutions' ${ }^{6}$, highlights a two-pronged fallacy inherent in such modernist view and secularist understanding of the modern nation-state: (i) that the various forms and sources of culture such as religion and nationalism have all been eroded and are now obsolete; and (ii) that because of their dissolution, modern nation-states are now molded exclusively through civic and secular processes including capitalist development, political democratization, social differentiation, secularization, and individualization. ${ }^{7}$ This heavy emphasis being placed on inclusive versus extractive economic and political institutions ${ }^{8}$ at the expense of cultural sources yields a simplistic and superficial conception of the modern nation-state that is characteristic of the modernization thesis and secularization logic.

On the contrary, the modern nation-states remain deeply embedded in much wider cultural meanings and structures that impact their national identities and their ideas about what should constitute their national interests. ${ }^{9}$ The overarching assertion that nation-states fail mainly due to their extractive economic and political structures invites two important questions. ${ }^{10}$ First, how do non-inclusive political and economic institutions emerge and get legitimized over time? If such institutions are to blame for the inequality and exclusivity that are causing nation-states to 'fail', why do they remain intact, especially when a significant portion of the population become their victims? Second, and relatedly, why do most nation-states continue to persist despite their continuing economic failures and political underdevelopment? How do such nationstates continue to possess effective control over their territory, their population, their government, and their diplomatic relations, despite the occasional challenges being posed by internal and/or external actors?

What most modernist and secularist analysis of the modern nation-state often fails and

${ }^{5}$ Friedman 2005.

' Acemoglu and Robinson 2012, 326.

? Hadden 1987; Przeworski and Limongi 1997; and Spohn 2003.

${ }^{8}$ Institutions are said to be extractive when they permit a small group of elites to rule over and exploit the rest of the population; whereas inclusive institutions allow the majority to be included and have a say in various governmental processes, thereby reducing the elite's capacity to abuse and manipulate. See, Acemoglu and Robinson 2012, 73.

- Bosco 2014; Fox 2003; Hall 2000; Norris and Inglehart 2011; and Snyder 2011.

${ }^{10}$ Hadden 1987; Przeworski and Limongi 1997; and Spohn 2003. 
neglect to explain are the most fundamental bases and origins of the factors that lead to the formation of institutions (both inclusive and extractive), and the processes through which these institutions (along with their constitutive elements) become normalized over time. ${ }^{11}$ The problem lies with the outright rejection of cultures as explanatory factors, presuming that these nonrational, nonmaterial elements have very little to do with the nature and type of institutions that develop within nation-states and how these are utilized. The multiple causes of material and nonmaterial layers of 'realities' constituting modern nation-states, and the complex mechanisms in which these layers interact, would suggest that these units are not exactly unitary rational actors, especially when multiple causal logics are operating at the same time. ${ }^{12}$ Yet, the myth that politics and economics could be separated and protected from the cultural compositions of nation-states remains.

Rather than rejecting cultural sources, specifically religion and nationalism, as archaic artefacts, I develop a framework that puts these nonrational, nonmaterial elements at the center of the analysis in order to: (i) explain why they remain crucial to the conception of contemporary nation-states; and (ii) understand how they are integral to the construction of both inclusive and extractive institutions designed to sustain them. Throughout history, both religion and nationalism have proved to be very powerful and durable engines for (re)negotiating the principles, norms, and rules of international society. ${ }^{13}$ The untold numbers of people who have offered their lives to protect their gods and nations speak to the breadth and depth of loyalty that these ideas hold even to this day. A 2018 survey conducted by the Pew Research Centre found that, on average $54.0 \%$ of adults say religion is very important in their lives. ${ }^{14}$ Similarly, the World Values Survey (2010-14) found that, on average, 57.1\% of adults were very proud of their nationality. ${ }^{15}$

Such is the case in Southeast Asia, a region characterized by high levels of religiosity and ethno-cultural heterogeneity. In the Philippines and East Timor, for instance, most of the population are predominantly Catholics (82.9\% and $96.9 \%$ respectively); in Indonesia, Malaysia

"See, Miyoshi 1993; Pecora 2006; and Steinmetz, 2018.

"2 Kaufman, 2019.

${ }_{13}^{13}$ Fox 2003; Petito and Hatzopoulos 2003; Seiple and Hoover 2004; Philpott 2007; and Marsden 2019.

${ }^{14}$ Pew Research Center 2017 and 2018.

${ }^{15}$ Institute for Comparative Survey Research 2019. 
and Brunei, they are largely Muslims (87.2\%, 61.3\% and 75\% respectively); and in Myanmar, Thailand, and Laos they are overwhelmingly Buddhists (87.9\%, 94.6\% and 64.7\% respectively). ${ }^{16}$ In all the countries mentioned, the share of population that says religion is very important in their lives ranges between $96.0 \%$ to $99.0 \% .{ }^{17}$ Beyond Southeast Asia, high levels of commitment to the dominant ethnic groups' primary religions also remain a reality. In South Asia, the share of population who view religious commitment to be very important is highest in Muslim-majority countries such as Afghanistan, Pakistan, Bangladesh, and Nepal, where more than $90.0 \%$ say it is very important. In sub-Saharan Africa, more than $80.0 \%$ of adults (except in South Africa and Botswana) consider religion to be very important, yielding a regional average of $89.0 \%$. In North Africa and the Middle East, at least $70.0 \%$ of the people surveyed in all countries (except in Lebanon and Israel) also agree that ethnoreligious commitment is very important. And in the Americas, religion is generally important to people in Central America and Latin America with regional averages of $81.0 \%$ and $77.0 \%$ respectively, and to a less extent, the United States with $53.0 \%$. Note that most of the government leaders as well as other elites in this region are members of the dominant faith within their respective locales and, as such, could potentially be influenced by the prevailing ethnoreligious and nationalist substructures (i.e. myths, doctrines, norms, and dogmas) they grew up with and continue to observe.

One of the likely outcomes that can emerge from this condition is that the security superstructures (i.e. rhetoric, policies, strategies, and institutions) which are being developed and implemented in these societies will tend to bolster and reaffirm the privileged status of the dominant ethnic groups and their religions. This domestic arrangement is particularly common in areas where the ethnicized religious identity of the majority becomes synonymous with the official national identity of the whole nation-state. As I argue throughout this paper, the amalgamation of security interests, religious motives, and nationalist aspirations, as imagined and defined by the dominant groups within specific territories, triggers a sequence of events aimed at strengthening the conceptual cohesion and reinforcing the material integrity of these

${ }^{16}$ Croissant and Lorenz 2018.

${ }^{17}$ Pew Research Center 2018. 
modern -and still primordial - nation-states, namely: cultivation of ethnoreligious nationalism, securitization of the 'othered' minorities, and sacralization of security superstructures.

In the next section, I briefly discuss the current state of the literature on nation-states, focusing on the limits of modernization and secularization theses in order to highlight the enduring relevance of religion and nationalism vis-à-vis the continued survival of nation-states. I then introduce my proposed framework and explain its main theoretical assumptions and arguments based on the three-way nexus between security, religion, and nationalism, namely: ethnoreligious nationalism, securitized minorities, and sacralized security superstructures. After which, I demonstrate the dynamics and processes through which these apparatuses emerge and work in Southeast Asia, particularly in Myanmar, providing an in-depth analysis and detailed illustration of how the nonmaterial ethnoreligious and nationalist substructures of the predominant groups give rise to material security superstructures designed to preserve the conceptual cohesion and material integrity of the overarching nation-state, and vice versa. Finally, I synthesize the key findings from my theoretical and empirical analysis, including the evidences from my fieldwork in Myanmar, and conclude that to considerable extent, the continued persistence of contemporary nation-states in highly religious and ethnically diverse regions is underwritten by sustained cultivation of ethnoreligious nationalism, securitization of the 'threat' of ethnoreligious minorities, and sacralization of security superstructures.

\section{State-of-the-art}

As a host of scholars have convincingly argued, the modernization and secularization theses are problematic when trying to understand the emergence, let alone persistence of nation-states alongside religion and nationalism. ${ }^{18}$ The likes of August Comte, Karl Marx, Émile Durkheim, Max Weber, Ferdinand Toennies, and Talcott Parsons all thought that the salience of religious and nationalist sentiments would steadily diminish as differentiation, rationalization and modernization of societies across the world advanced. Based on their analyses, religion and nationalism were just transitory stages within a social evolution continuum, that is, from 'a

\footnotetext{
${ }^{18}$ Smith 1983; Guiberneau 1997; Imhof 1997; and Thompson and Fevre 2001.
} 
traditional, communitarian, ascriptive, bourgeois or pre-rational phenomenon to rationalized and individualized class society based on achievement. ${ }^{19}$ In short, religion and nationalism were expected to become obsolete either by Marx and Friedrich Engels' proletarian internationalism and/or by Durkheim's post-patriotic human ideals. And as a consequence, the militarytheological system would collapse and would be superseded by a modern secular system. Such shortsightedness could be attributed both to the division of labor between academic disciplines and a methodological problem, resulting in a systematic blindness toward the paradox that modernization has, in fact, helped create even more religious and nationalist communities amidst a supposedly modernizing international society..$^{20}$

It was only after the fall of the Soviet Union and the demise of virtually all socialistcommunist projects that the parallel development of religion and nationalism has proliferated on a worldwide scale, leading to various associated phenomena including the growth of ethnic nationalism, the revitalization of religion, the resurgence of religious fundamentalism, and the rise of religious nationalism. ${ }^{21}$ These events surprised many in the social and political sciences as they challenged the almost universally accepted frame theories and analytical orientations of the modernist and secularist paradigms. More specifically, a secularist bias in the study of nationalism obfuscated interesting relations between religion and nationalism in favor of modernist assumptions underlining the political, socioeconomic, and cultural forms of modernity. ${ }^{22}$ Proponents of these thoughts mainly saw religion as being replaced by nationalism rather than contributing to the emergence and advancement of nationalism; or that conversely, nationalism was an antithesis to religion, a consequence of religion's decline. Either way, the result was a widely shared understanding of a modern nation-state that consigned religion to the realm of the private. ${ }^{23}$

This has been and continues to be manifested in international relations which has its origin in the rejection of religion, more specifically, 'the belief that era in which religion caused war was

\footnotetext{
19 Wimmer and Schiller 2002, p. 303.

${ }_{20}$ Smith 1983; and Wimmer and Schiller 2002.

${ }_{21}^{21}$ Marty and Appleby 1987; Beyer 1994; Haynes 1998; Jürgensmeyer 1993; Huntington 1996; and Spohn 2003.

${ }_{22}$ On political modernity, see Deutsch 1953 and Gellner and Breuilly 1983; on socioeconomic modernity, see Breuilly 1993; Hechter 2000; and Tilly 1996; and on cultural modernity, see Anderson 1983.

${ }^{23}$ Brubraker 2012.
} 
over'. ${ }^{24}$ Efforts to find more rational as opposed to supernatural explanations for human behavior in the age of scientific revolution were pursued at the expense of religion. This desire to depart from the influence of religion was captured by Voltaire's argument that the age of enlightenment would bring an end to superstition and the religious authoritarian order. ${ }^{25}$ This vision has resonated well into the future as renowned political scientists including the likes of Gabriel Almond, David Apter, Karl Deutsch, John Kautsky, and Donald Smith have all pushed forward the idea that modernization would reduce, if not completely abolish, the political currency of primordial phenomena such as religion and ethnicity. ${ }^{26}$ Even in the $21^{\text {st }}$ century, scholars and experts continue to debate over the influence of religion on modern societies on two fronts: (i) whether secularization means people are becoming less religious or pertains to the decline in influence of religion on socio-political institutions; and (ii) whether either of these processes is, in fact, taking place. ${ }^{27}$

From these debates, counter-analysis and arguments revealing that modernization has actually resulted in the resurgence and revitalization of religion have emerged. Jonathan Fox has synthesized these findings in three categories. ${ }^{28}$ First, as far as the so-called Third World is concerned, attempts at modernization have been unsuccessful in weakening the values and traditions of local tribal communities, creating backlash of repressed grievances and resentments by religious/nationalist movements. At the individual level, the failed promise of modernization resulted in alienation, confusion, and displacement of people, exposing them to religious/nationalist actors that swore to protect their identity and homeland. ${ }^{29}$ Second, instead of diminishing the operational fields of religious/nationalist movements and governments, the process of modernization had the paradoxical effect of expanding their respective domains, resulting a collision between these two forces. ${ }^{30}$ Modernity has not only given religious/nationalist agents access to political processes, but also facilitated the nationalization as

${ }^{24}$ Fox 2001, p. 55-56. See also, Laustsen and Waever 2000.

${ }_{25}^{25}$ Appleby 1994.

${ }^{26}$ Deutsch 1953; Almond and Coleman 1960; Apter 1965; Smith 1971; and Kautsky 1972.

${ }^{27}$ Juergensmeyer 1993; Haynes 1994; Stark 1999; Thomas 2000; and Fox 2001.

${ }_{28}$ Fox 2001, 2008, 2018.

29 Sahliyeh, 1990; Juergensmeyer 1993, 1996; Haynes 1994, 2016; and Eisenstadt 2000.

${ }^{30}$ Rubin 1990; Eisenstadt 2000. 
well as globalization of their perceived local struggles and causes. ${ }^{31}$ And third, the freedom of religion that has become a central ethos of modern societies has been linked to an increase in level of individual religiosity. With the breakdown of religious monopolies in much of modern world, according to the rational economic theory of religion, people of faith have started applying costbenefit analysis in choosing their own religion; while at the same time, religious 'entrepreneurs' have bolstered their efforts in making their religion more attractive and marketable to prospective 'buyers.' ${ }^{2}$ This 'free market' of religion is said to have made people consume more religion, thereby increasing their level of religiosity. ${ }^{33}$

The framework presented here is based on the synthesis and amalgamation of complementary theories on security, religion, and nationalism which have been developed by previous scholars from different fields, mainly, Sociology, Anthropology, International Relations, and Political Psychology. The main rationale for constructing the framework is to facilitate a more methodical but still nuanced approach to understanding the role and impact of these nonrational, nonmaterial elements with respect to certain political trends, events, and societies across the world. Dismissing their presence and influence just because their exact forms and manifestations cannot be physically seen and measured is damaging not only to security experts who insist on focusing exclusively on the material, quantifiable ways of examining political phenomena, but also to the leaders and policymakers they advise. Proper analysis has often been the casualty of excessive reliance on modernization and secularization theories, resulting in profound misinterpretations and miscalculations. The development and application of this framework highlights the scholarly predispositions against the unseen and the unquantified, and address the issues that result from these. It does so by providing a thick qualitative description and analysis of the enduring relevance of religion and nationalism, specifically in relation the survival of modern nation-states, so that scholars who may wish to employ quantitative methods will have a more solid basis on which to develop the variables in their models.

\footnotetext{
${ }^{31}$ Fox 2001.

${ }_{32}$ Warner 1993; Iannaccone 1995; and Olson 2009.

${ }^{33}$ Iannaccone 1995; and Fox 2001.
} 


\section{A Framework for Understanding the Persistence of Nation-States}

\section{TRACK 1: CULTIVATING ETHNORELIGIOUS NATIONALISM}

Ethnoreligious nationalism denotes the amalgamation of ethnicized religious identity and nationalism, creating a condition that compels collectivities to establish, develop, and safeguard their conceptions and narratives of nation-statehood in ethnoreligious terms. ${ }^{34}$ When fused together with nationalism, ethnicized religion provides state and religious actors (both the dominant and the minority) with a powerful tool that they use not only for masking certain materialist interests but also for ascribing identity. The resulting phenomenon of ethnoreligious nationalism offers these key players a useful and effective lexicon for framing and legitimizing political mobilizations that will either solidify or abolish existing power hierarchies as they deem fit. Based on this formulation, the concept performs two important functions: (i) opening a channel through which identity differentiations are structured, on the assumption that ethnicized religions ascribe identities to collectivities which distinguish and separate them from one another; and (ii) creating a source of legitimacy which enables the consolidation of powers and conscription of social forces for the protection of the "natural" rights of competing ethnoreligious groups within territorially bound states. ${ }^{35}$

This means that the approaches influenced by modernization theory, which presume the evolutionary decay and obsolescence of primordial components such as religion and ethnicity, are in many ways flawed. For one, despite the seemingly increasing trend toward secularism amidst the advancements of modernization processes, religion and ethnicity remain constitutive dimensions of modern national identity and nationalism, particularly in regions like Southeast Asia. The modernization of traditional ethnic communities and societies against the backdrop of "globalization" has not been complemented by a similar movement toward secular and civic forms of nationalism. ${ }^{36}$ In contrast to the common assumption that secularization instinctively abhors the presence of primitive and folkloric elements, the process does, in fact, develop in

\footnotetext{
${ }^{34}$ Juergensmeyer 1993; Hastings 1997; Baumann 1999; and Kinnvall 2004.

${ }^{35}$ Juergensmeyer 1996; Friedland 2001; Spohn 2003; and Brubaker 2011.

${ }_{36}$ Pecora 2006; and Beyer and Beaman 2007.
} 
varying patterns, blending religious and secular components together. ${ }^{37}$ This challenges the idea that nationalism and national identity are progressively evolving into secular forms, as they are continuously being shaped and reshaped through ethnoreligious frames. Indeed, the reemergence of religion and nationalism to the forefront of international relations in the twentyfirst century highlights the theoretical cracks undermining the modernization-cum-secularization thesis.

One of the primary hypotheses here is that the resurgence of nationalism and particularistic religious fundamentalism is indicative of the growing resistance of nation-states toward a world system underpinned by globalization forces..$^{38}$ On the one hand, ethnoreligious nationalism can be attributed to the clashing processes of secular nation-state formation amidst high levels of ethnic and religious heterogeneity and low levels of democratic pluralization. ${ }^{39}$ This view is rooted in the idea that globalization serves as a vessel for transplanting western style modernity, enabling the worldwide spread of the nation-state and capitalist production, as well as the homogenization of national cultures. ${ }^{40}$ On the other hand, ethnoreligious nationalism can also be deemed as a form of political, social, and cultural protest against the institutionalization of a core-periphery order engendered by a capitalist international system..$^{41}$ This idea is based on the general perception that the global proliferation of the western framework has altered the circumstances of each nation-state, accentuating social distinctions and triggering counterreactions. ${ }^{42}$

These points have two main implications: (i) that, far from being universal, western modernity is just one of the many varieties of modernity that are evolving simultaneously in different civilizations across the world; and (ii) that non-western modernization cannot be simply equated with westernization because it involves the incorporation of western influences and impacts in non-western civilizational dynamics, programs of modernity and modernization processes. ${ }^{\prime 3}$ Ethnoreligious nationalism, in this sense, is a powerful basis and reservoir of

37 Hastings 1997; Brubaker 2004; and Pecora 2006.

${ }_{3 s}$ Barber 1992; and Huntington 1993.

${ }^{33}$ Baumann 1999; van Der Veer and Lehmann 1999; Spohn 2003; and Steinmetz 2018.

40 Tomlinson 1999; and Holton 2011.

"Juergensmeyer 1993; Smith 1998; and Beyer and Beaman 2007.

"2 Barber 1992; and Huntington 1993.

${ }^{4}$ Baumann 1999; Spohn 2003; and Kinnvall 2003. 
identity: an expression of a culture's sovereignty in the form of nationalist ethnic and religious clusters. ${ }^{44}$ Nationalism signifies a form with variable content; whereas ethnicized religion acts as an implement that specifies the content of this form..$^{45}$ While nationalism stipulates the necessity of binding the state, territory, and culture together without determining the methods and contents of this amalgamation; ethnicized religion offers a distinctive method and content by constructing 'models of authority' and 'imaginations of an ordering power' which control and regulate the various of facets of life. ${ }^{46}$ Thus, contrary to the assumptions underpinning secular nationalism, ethnoreligious nationalism remains integral to the configuration and continuation of nation-states by providing the sources for the form and content of these units.

In its most radical and extreme form, the narrative of ethnoreligious nationalism claims that the nation-state is ultimately responsible for the protection and preservation of the majority ethnic group's religion. ${ }^{47}$ Here, the leading confessional faith and the native land are portrayed as irreversible and fixed components of the individuals' identity that constitutes the core essence of conceptions about nation-statehood, 'and in which the territorialization and institutionalization of this identity is vested.' ${ }^{8} 8$ Accordingly, crafting a language that helps revitalize, reproduce, and secure this ethnicized religious identity is fundamental to the salvation of a nation-state. To this end, religious imageries and themes are constantly mined to build the necessary ethnocultural and ideological foundations which enable the dominant elites to seize and enhance control over the prevailing nation-state..$^{49}$ Conversely, these ethnoreligious sources are also accessed and employed by minor elite players who might be pushing for independence from a government that promotes discriminatory policies against them, or at least demanding equal constitutional rights..$^{50}$ In this regard, ethnoreligious nationalism is a medium through which grassroots support and sentiments are summoned to either defend the prevailing status quo or to contest and overthrow this pre-existing social arrangement. In any case, dominant elite actors use state apparatuses to exploit religion's utility for configuring identities, affecting

"Hastings 1997; Friedland 2001; and Brubaker 2011.

${ }^{45}$ Gellner and Breuilly 1983; Friedland 2001; and Brubaker 2011.

${ }^{40}$ Friedland 2002, 390.

${ }^{47}$ Juergensmeyer 1993; and Brubaker 2011.

* Liow, 2016, 47.

${ }^{4}$ Hastings 1997; Van Der Veer and Lehmann 1999; and Kinnvall 2004.

so Armstrong 1997; and Liow 2016. 
behaviors, and rallying the ranks into actions; while simultaneously suppressing all opposing versions of the nation-state that threaten to delegitimize and undermine its existence. ${ }^{51}$

Ethnoreligious nationalism becomes a matter of identifying who gets to legitimately define the foundation and constitution of the national identity that will inform the state's frame of governance amidst the presence of deeply polarized ethnoreligious cleavages. It does not simply impute identity to the project of building and maintaining a nation-state, but also establishes the 'chosen glories' and 'chosen traumas' that must be preserved ${ }^{52}$, the discourses and narratives that must be favored, and the memberships and allegiances that must be agreed upon. Put differently, manufacturing a homogenous national culture and composing a master tale of the nation-state for the ultimate purpose of constructing an "ideal" and a "legitimate" national identity, is contingent on the marginalization of other forms and sources of collective histories, memories, and loyalties. ${ }^{53}$ National identity construction and nation-state formation, therefore, are not defined based solely on the people's exclusive commitment to a modern charter or a secular constitution, but instead, these processes are also embedded and expressed along deeply entrenched ethnoreligious fault lines.

\section{TRACK 2: SECURITIZING THE ‘THREAT’ OF ETHNORELIGIOUS MINORITIES}

Dissecting the securitization of 'existential threats' of the 'othered' minorities by powerful state and religious actors provides vital insights about how ethnoreligious nationalism influences the framing of nation-states, and how it inspires mobilization efforts and their outcomes. In this process, ethnoreligious nationalism works as a vehicle for defining and molding collective identities and practices; marking and preserving political rights and duties; and creating and reproducing alliances and cleavages of national security. ${ }^{54}$ Here, ethnoreligious minorities are framed as threats to the security of the dominant group and the prevailing 'natural' order due to their anti-status quo conceptions and narratives of the nation-state. It is driven by the attempts of the dominant elites to identify the majoritarian religion and its followers as the legitimate referent

"siddens 1987; Stavenhagen, 1996; Hughey 1998; and Ashmore, Jussim and Wilder 2001.

${ }^{52}$ Volkan 1998.

smith 2003; and Zubrzycki 2017.

${ }^{54}$ Fox 2003; Philpott 2007; and Marsden 2019. 
objects of security. The underlying view is that measures must be taken to protect the one 'true faith' from the destructive existential risks emanating from the minorities' 'false religions' that spread 'wrong', 'distorted', and 'perverted' beliefs about the ideal constitution and function of the nation-state.

Consequently, the depiction of alternative 'ethnic' religions as sources of national insecurities and threats to the existing arrangement is becoming a necessity that must be constantly reproduced and repeated. In contrast, the powerful state and religious actors are able to defend their position that providing state protection for the majority religion is a precondition for national security, because to preserve this faith and its community is to preserve the national identity and territorial integrity of the nation-state. This ultimately results in an internal security dilemma in which the power and security of the prevailing nation-state, ultimately rests upon the relative insecurity and weakness of the othered minorities. Despite the catastrophic effects of this type of domestic configuration, it is exactly these domestic power differentials and imbalances which underpin the integrity and cohesiveness nation-states within highly religious and ethnically heterogeneous contexts.

Traditionally, nationalism has been viewed as a means of defining the 'self' vis-à-vis the other, where the other is external to the overarching nation-state. But with a particularistic (as opposed to universalist) ethnoreligious nationalism, this 'other' is also an insider living within the borders of the nation-state. Security, as what Barry Buzan, Ole Wæver, and Jaap de Wilde claim, is self-referential precisely because 'an issue becomes a security issue, not necessarily because a real existential threat exists but because the issue is presented as a threat. ${ }^{\prime 55}$ Rather than thinking of security as being tangible, it must be viewed as a process via which actors are able to frame specific issues as threats to security. ${ }^{56}$ The Copenhagen School refers to those actors that 'are placed in positions of power by virtue of being generally accepted voices of security' as securitizing actors and, as such, are commonly regarded as 'holders of the collective identity. ${ }^{\prime 57}$ While in theory everyone can take the role of a securitizing actor, in practical terms, the Copenhagen School's understanding of security as a structured field implies that state and non-

ss Buzan, Wæver and ae Wilde 1998, 24.

so Wæver 1995.

s" Buzan, Wæver, and de Wilde 1998, 23. 
state elites are better positioned to develop and propagate legitimate security discourses given their social capital and overall knowledge of the context. ${ }^{58}$

By elevating specific issues as security matters, these securitizing actors are able to substantiate the adoption of certain emergency measures which entail the infringement of already established rules and/or the circumvention of normal political processes. A securitization act does not merely depict the realities underpinning the current security conditions; it plays an active part in the construction and deconstruction of these realities. ${ }^{59}$ Accordingly, it brings about new approaches to self-understanding and collective identity, which in turn, influence the community's perceptions about the 'real' threats to their security and existence, and who must be protected from these threats. In other words, it is by positing the security threats and identifying the referent objects that they are brought into being. As Wæver has succinctly put it, 'the word security is the act', which is to say that security is essentially a speech act. ${ }^{60}$

To securitize the issue of ethnoreligious minorities is to frame them as threats to the collectivity which the securitizing actors claim to represent. This, in turn, necessitates the construction of 'us' versus 'them' narratives designed to bind the communities together by accentuating the differences between the members and the outsiders rather than emphasizing their similarities. Accordingly, how the others are conceived is an integral component of how the ethnoreligious majority view and understand themselves. Defining and differentiating the insiders vis-à-vis the outsiders is essentially rooted in the power positions underlying the prevailing nation-state that favor the majority group. As the threats and anxieties confronting the religious majority intensify, so does the impetus for the dominant elites to impose a mix of inclusive and extractive security superstructures intended to weaken the minorities' ethnoreligious and nationalist substructures and suppress their own imagined communities, where they exist. This means that the continued primacy of the status quo nation-state ultimately relies on the preservation of the respective structural power positions between the dominant and the minority ethnoreligious groups. The more that the othered minorities are vilified in the public sphere and presented as threats to national security, the greater the exclusion and hostility that

ss Ibid., p. 31

s9 Stritzel 2007; and Balzacq 2010.

${ }^{6}$ Wæver 1995, 55. 
they are bound to confront, forcing many of them to reexamine and revisit their own ethnies and religions to help anchor and secure their identities.

Catarina Kinnvall (2004)'s formulation of the 'abject-other' helps elucidate how the securitization of the 'threat' of othered minorities engenders a domestic security dilemma. In depicting the once familiar 'others' as security threats, the 'abject' becomes a key component of collective identity formation. ${ }^{61}$ Turning the others into enemies requires their systematic debasement and dehumanization. This results in the perception of the others as being 'dirty, despicable and worthless nonhumans. ${ }^{\prime 2}$ Yet it is this very process that enables the majority (particularly those who have been swept away by ethnoreligious nationalism) to feel more secure and less anxious about their own standing, as it gives them the assurance that they are fundamentally different from - indeed, superior to - the others. By projecting anything that may be deemed as an objectionable or threatening characteristic of the self onto the other, the powerful elite actors are able to sacralize themselves and the members of their own faith, while continuously demonizing the minorities and their religions. ${ }^{63}$ With the effective diminution of the others into inhumanity, all security measures that are believed to help preserve the imaginary boundaries between the 'pure' self and the 'dirty' others are justified and defended.

Consequently, discourses based on exclusion and segregation are created and propagated, enabling the core state and ethnoreligious players to mobilize the majority members against the others. In the words of Robert Robins and Jerrold Post, 'the movement must strengthen its walls against the enemy without and search for enemies within... true belief does not permit question and doubt.' ${ }^{64}$ By facilitating a certain level of attitudinal conformity among their followers and supporters, these dominant elites become powerful norm and discourse entrepreneurs. ${ }^{65}$ Dominant state elites help their ethnoreligious counterparts supportive of their policy measures by providing the hard power needed to secure the position of their ethnie and religion within the nation-state. Similarly, dominant ethnoreligious leaders help their state counterparts supportive of their faith by providing the soft power needed to further legitimize their authority and rule

"Kinnvall 2004.

${ }^{62}$ Ibid., 753.

${ }^{6}$ Ibid., 754; see also, Kristeva 1991; and Volkan 1998.

${ }^{64}$ Robins and Post 1997.

${ }^{6}$ Hassner 2003; Karyotis and Patrikios 2010; and Bosco 2014. 
over the nation-state. The perceived differences between the majority and the others are then increasingly viewed as natural and intrinsic features that distinguish and separate the legitimate insiders from the illegitimate outsiders.

A securitization discourse, therefore, plays a pivotal role in shaping and reshaping people's understanding and interpretation of reality. When these presentations of reality reach an authoritative status with the effective securitization of the threat, the discourses that have been conceived and crafted by the dominant elites become socially powerful and get construed as the only correct and worthwhile perspectives. These attempts at securitizing the issue of ethnoreligious minorities using the fuel provided by ethnoreligious nationalism, underscore the malleability of ethnoreligious and nationalist substructures, and how powerful actors are simultaneously utilizing and being influenced by these factors to construct security superstructures that promote and legitimize a specific vision of the nation-state especially in times of insecurity and unrest.

\section{TRACK 3: SACRALIZING SECURITY SUPERSTRUCTURES}

Far from being separate spheres, security politics and ethnoreligious affairs are intimately intertwined. National security interests are subjectively defined and pursued via a political process that owes little to the logic of strategy but a great deal to the logic of domestic politics. ${ }^{66}$ With the cultivation of ethnoreligious nationalism (track 1) and securitization of the 'threat' of othered minorities (track 2), the dominant elite actors further solidify the legitimacy and position of the primary nation-state by sacralizing the state security superstructures that underpin the existing order and the power dynamics within it. They do so by embedding and reproducing the prevailing ethnoreligious and nationalist substructures (i.e. doctrines, myths, dogmas, and norms) of the majority, within and across various instruments of power and statecraft, notably in the security rhetoric, policies, strategies, and institutions (i.e. superstructures) of the hegemonic nation-state.

To this extent, national security becomes a continuation of ethnoreligious nationalism by other means. It serves as a device used to justify the mobilization of ethnoreligious societies

\footnotetext{
${ }^{"}$ Luttwak 2001, 182.
} 
for/against war and peace: placating the insiders that demand greater rights and exclusive privileges on the basis of their ethnic and religious affiliations, while taking an aggressive stance against the outsiders who might threaten this order. The peripheral positions of minority groups render their own ethnoreligious and nationalist substructures too weak to stimulate the creation of security superstructures that would have given them a bigger voice and space within the established nation-station. These dynamics make the existing order look right and natural, one that must be preserved despite the systematic marginalization of the othered.

Due to the role of ethnoreligious nationalism as a medium for understanding the constitution of being as such', those who subscribe to it cannot afford be too rational when dealing with issues that question and opposed this being. ${ }^{67}$ This suggests that state actors do not just politicize ethnoreligious and nationalist substructures to legitimize their construction and employment of the security superstructures, their conduct of politics and the political channels through which they function are also infiltrated by these nonrational, nonmaterial components. Regardless of whether they are substantively bound (i.e. actors are genuinely motivated) by the narratives and conceptions of ethnoreligious nationalism or are only tactically constrained (i.e. strategically utilized by actors), drawing upon these substructures is useful for legitimizing the prevailing nation-state, as well as keeping their position of authority, influence, and power within it.

This condition is especially relevant among nation-states that have experienced colonialism, whose boundaries and borders are relatively recent and fragile such as those found in Southeast Asia. In many of these locales, ethnoreligious elites are often deemed as the ultimate custodians and interpreters of national identity, enabling their homilies to outweigh those supposedly secular political discourses. ${ }^{68}$ Such perceptions and attitudes toward these actors make them seem more credible and trustworthy than their political counterparts. Concepts of right and wrong or just and evil are largely understood by individuals and societies through ethnicized religious teachings and practices that are observed within their indigenized religious communities. This form of social power helps transform the leaders of the main ethnoreligious

${ }^{6}$ Laustsen and Waever 2000, 719.

${ }^{6}$ Johnston and Sampson 1995; Fox 2003; and Petito and Hatzopoulos 2003. 
faction into divine authority figures, allowing them to influence the powerful political elites who are responsible for the construction of the state's security superstructures. Because these belief systems are indispensable to the individuals' thought processes and societal consciousness, anything that threatens their credibility and infallibility is customarily ignored or suppressed. ${ }^{69}$

The situation becomes even more pronounced when the ethnicized religious identity of the majority overlaps and is conflated with the perceived national identity of the specific locale. By projecting themselves and the institutions they represent as guardians of national identity, ethnoreligious authorities in these states hold substantial influence over the sacralization of the security superstructures that are crafted. ${ }^{70}$ On the one hand, the myths and doctrines of the ethnoreligious majority are heavily informing the security rhetoric and policies being developed by state elites, which identify the legitimate referents of national security and measures for addressing the threats to these referents. On the other, the security strategies and institutions that are eventually adopted by state officials are deployed in ways that also legitimize and entrench the norms and dogmas observed by the core ethnoreligious group.

Overtime, the ethnoreligious and nationalist substructures acquired and exploited by a group, and the security superstructures devised based upon them, become intractable, axiomatic components of nation-state building. Together, they fortify the foundations of the 'home': a place where that 'one stable identity' can be anchored and secured, thereby, 'giving both protection and safety from the stranger, the abject-other.' ${ }^{71}$ Implanting ethnoreligious nationalism when configuring national security sacralizes the security superstructures which are produced to guard and protect this home. Criticisms and oppositions against these policies and the regime that spurred them are avoided because to do so can be interpreted as a rebellion against 'God' and its most favored religion, in short, a national security issue.

Since a sacred territory cannot be shared, it becomes a gory reward in 'just wars' which are carried out to subdue and/or completely banish the othered. Most religions, particularly the monotheistic ones, believe in some form of just war theory. ${ }^{72}$ Many of these faith groups recognize

* Wentz 1987; Robins and Post 1997; and Kinnvall 2004.

${ }^{20}$ Laustsen and Waever 2000; Fox 2003; and Lucius 2012.

"Kinnvall, 2004, 762.

"Elshtain 1992; and Hassner 2007. 
that war and bloodshed may sometimes be necessary especially when dealing with outside entities suspected of destroying the foundations and purity of the home. The illusion of a 'pure identity' (through cultivation of ethnoreligious nationalism), coupled with the myth of 'chosenness' (through securitization of othered minorities) underlies the quest toward an ethnically and religiously pure home. Establishing who the real 'chosen ones' are, then becomes a paramount issue.

To weed out the impostors from the legitimate chosen people, a just war is set in motion, paving the way for the symbolic rejection and social expulsion of the others into the 'zone of killing. ${ }^{173}$ Whereas ethnoreligious nationalism provides the ideology for adopting just wars, the sacralized security superstructures provide the means and channels for executing the operations that these wars entail. To borrow some of Michael Ignatieff's words, a nation-state is a fantasy land where the political and cultural boundaries perfectly align to resemble a congregation, enabling the people to sing and waltz to the same anthems, absorb and live by the same gospels, feel and communicate the same emotion, and 'linked not only to each other, but to the dead beneath their feet. ${ }^{\prime 74}$

\section{Cultivating, Securing, and Sacralizing a Nation-State: The Case of Myanmar}

\section{CULTIVATING A ‘BURMAN BUDDHIST’ NATIONALISM}

The cultivation of ethnoreligious nationalism in Myanmar (known as Burma until 1989) has been largely precipitated by the brutalities of the British colonial rule that lasted from 1824 to 1948. Through their shared Buddhist religion, the Burmese subjects were able to consolidate their anticolonial stance against a repressive foreign power that divided and ruled ethnic communities using policies of racial hierarchization. The Burmese king and his monks saw the British empire as a threat to Buddhism and fought hard against the conversion of their people to Christianity, fearing that they might be used by the colonizers to undermine their own power and position in

\footnotetext{
Stevens 1997.

${ }^{74}$ Ignatieff 1993, 95. See also, Horowitz 2010.
} 
the society. ${ }^{75}$ For the local ruling elites at that time, Christianization was not simply meant to convert the king's subjects to a different faith and a set of belief systems, it was a tool designed to subvert the Burmese people's loyalty and allegiance to the monarchy and the Sangha by transforming them into kala or foreigners. ${ }^{76}$ Moreover, the colonial administrative strategy of establishing a plural society prevented the British rulers from fully appreciating the extent to which religion shapes and defines ethnic Burmese identity, as well as its capacity for triggering future clashes. ${ }^{77}$ The idea that people of different ethnic and religious groups could meet and interact in market places while observing their own beliefs and customs within their respective communities, did not do much in placating the Buddhist majority who felt grave injustice at the abolishment of the monarchy and the relegation of Buddhism to the sidelines.

These decisions propelled the formation of early ethnoreligious and nationalist movements in Myanmar such as the Young Men's Buddhist Association (YMBA) which the monks used to mount their protest against the British colonizers. ${ }^{78}$ To many of the Buddhist majority in Myanmar, the attempts of their monks to voluntarily participate and intervene in secular politics are symptoms of government ineffectiveness and indifference. ${ }^{79}$ This view justifies the calls and actions of the powerful monastic community for virtuous defense of ethnicized Buddhism, since the general health of religion and the overall stability of the polity are ultimately intertwined..$^{80}$

Here, we see how the rise of Burman Buddhist nationalism in Myanmar has precipitated the idea that the dominant Buddhist faith and the indigenous land are intrinsic and permanent features of the individuals' identity which, in turn, informs the core composition of Burman narratives and conceptions about nation-state formation. By portraying the Burman Buddhist identity as the primary referent of territorialization and institutionalization of nation-statehood in Myanmar, the case is made that the government has the obligation to protect the dominance of the majority ethnic group and defend its faith. This drives the creation of nationalist rhetoric

${ }^{75}$ Author's interview with a key informant in Yangon, Myanmar on Aug 21, 2017.

${ }^{76}$ Gravers 2015.

"Furnivall, 2014.

${ }^{78}$ Matthews 1993; and Gravers 2015.

" Author's interview with a key informant in Yangon, Myanmar on August 21, 2017.

${ }^{s 0}$ Gravers 2015; and Schissler, Walton and Phyu Phyu Thi 2017. 
designed to stimulate, propagate, and secure the dominant identity, using imageries and symbols that are mined from the ethnoreligious and cultural reservoirs of the majority Burman Buddhists. Apart from being matters of personal conviction and veneration, ethnoreligious nationalism possesses deep-rooted 'socio-political resonances' and 'communitarian associations' in the same manner that the territory encompasses not only physical space but also metaphysical assertions about 'homelands' and 'sons of the soil.'s1

Not surprisingly, when a book allegedly written by a Muslim got reprinted in 1938, the monks passed a resolution demanding that the author be punished for purportedly mocking and threatening to exterminate Buddhism and its language. ${ }^{82}$ The Buddhist monks and their followers warned that if nothing was done, 'steps will be taken to treat the Muslims as enemy number $1 \ldots$ and to bring about the extermination of Muslims and the extinction of their religion and language.' ${ }^{83}$ Guided by their slogans of 'Burma for Burmans' and 'Master Race We Are, We Burmans', the ensuing Dobama Movement resulted in the killings of 192 people of Indian descent and the arrests of more than 4,000 individuals. ${ }^{84}$

This incident illustrates how the propagation of Burman Buddhist nationalism has created a medium through which identity distinctions have been conceived and constructed to segregate the 'illegitimate' out-group from the 'legitimate' in-group. The 'chosen glories' and 'chosen traumas' of the dominant ethnoreligious group have been elevated and used as sources for determining the legitimate foundation and constitution of the national identity of the Myanmar nation-state. ${ }^{85}$ Doing so has provided the majority ethnoreligious group with a potent lexicon for framing the otherness and strangeness of the minorities; and has rationalized the dominant elites' mobilization efforts against the 'enemies' to preserve the ideal 'ethnic Buddhist' identity of the nation-state, along with their 'natural' rights and privileges. Attempts to produce a homogenous national culture and a grand narrative of the nation-state on the basis of an 'ideal' Burman Buddhist identity, have relied heavily on the exclusion of the minorities' collective histories, memories, and loyalties.

${ }_{81}$ Tambiah 1996, 16.

s2 Smith 1965, 109.

${ }_{83}$ Ibid.

s: Cady1958; Khin Yi 1988; and Nemoto 2000.

ss Volkan 1998. 
Viewed this way, the emergence and spread of Burman Buddhist nationalism has facilitated a distinctive method for conjoining Myanmar's state, territory, and culture together by generating 'models of authority and imaginations of an ordering power.'s6 The purpose of which is to sustain and enhance the cohesiveness and integrity of the hegemonic nation-state by suppressing other 'foreign' nationalisms and their 'alien' imagined communities. To this extent, the development of ethnoreligious nationalism is not simply an attempt by the dominant elites to conceal their material interests. Rather, it is also an apparatus for ascribing identity to the process of creating and preserving a nation-state, by determining the legitimate memories that must be defended, the legitimate discourses that must be preferred, and the legitimate forms of loyalty that must be permitted. Accordingly, national identity construction and nation-state formation in Myanmar are not exclusive byproducts of modern charters and secular constitutions, but are interwoven within, and manifested across deep-rooted ethnoreligious cleavages. By providing the sources for the form and the content of nation-states, these nonrational, nonmaterial components remain vital to the constitution and persistence of these units.

\section{SECURITIZING THE ‘ROHINGYA THREAT’ IN RAKHINE}

The securitization of the 'problem' of Rohingya Muslims in Myanmar underscores how the cultivation of Burman Buddhist nationalism has resulted in the framing of this ethnoreligious minority as an 'existential threat' to the security of the Burman Buddhists, as well as the stability of the prevailing nation-state. Efforts by the dominant elites to portray the ethnic majority and their faith as primary referents of national security are driven by underlying views that the minorities' ethnoreligious and nationalist substructures are detrimental to the existing 'natural' arrangement. In Myanmar, the emergence and proliferation of the myth of Burmese deracination due to the perceived 'Islamization' of the country, has driven the demand for pro-Burman Buddhist constitutional instruments. ${ }^{87}$ The consequent 'Burmanization' of national identity has led to the creation of highly discriminatory legislations designed to subjugate and fit the religious minorities into a Buddhist-configured vision of an ideal Burmese nation-state. ${ }^{8}$

${ }^{8}$ Friedland 2001, p. 390.

${ }^{8}$ Nyi Nyi Kyaw 2016.

s Berlie 2008; and Nyi Nyi Kyaw 2016. 
Such a strategy for 'unifying' Myanmar's ethnoreligious groups justifies the restrictions being imposed on the religious freedom of the minorities, along with other forms of human rights abuses committed by state elites and civilians. The Citizenship Law passed in 1982 is a crucial component of a series of actions implemented by the nationalist government intended to shore Burman ethnic power by securitizing the 'Rohingya threat'. Under this law, a person is given a color-coded Citizenship Scrutiny Card that corresponds with the status of his or her citizenship and the rights that come with it: pink for full citizenship, blue for associate citizenship, and green for naturalized citizenship. Citizens must carry these cards at all times which include information about their religious affiliations (only one) and ethnic identities (which can be one or more). ${ }^{89}$

A full citizenship is granted only to members of the eight 'indigenous races' (taing-yin-tha) which the state had identified and believed to have already settled in Myanmar before the start of British occupation in $1824 . .^{90}$ Other ethnic groups not mentioned on the list are denied citizenship, and are prevented from possessing identity cards. ${ }^{91}$ By significantly curtailing, if not, completely denying the rights of those who do not meet the citizenship criteria, the law has effectively stripped the normative basis for an individual's legal rights on the guise of protecting the legitimate Burmese. ${ }^{92}$ The state's absolute authority for determining which groups are deserving of citizenship gives it a powerful tool for securitizing minorities that are considered threats to the integrity and cohesion of Myanmar's nation-statehood.

This is exactly what happened to the Rohingya Muslims who have been deprived of their Burmese nationality. The Citizenship Law has unfavorably reconstructed the image and identity of the group by delegitimizing the bases of their ethnic claims, making them world's largest stateless population within a country today. Despite being able to trace the group's history to the eight century, in the eyes of the ruling government and majority of Burmese citizens, the Rohingyas are 'resident foreigners.' Most Burmese residents in Rakhine even suggest that these 'Bengalis' (as what they are called in Myanmar), are illegal immigrants who came from Bangladesh and only settled in Myanmar as recently as a few years ago. ${ }^{93}$ One of the implications

${ }^{89}$ Cheesman 2017.

${ }^{9}$ Human Rights Watch 2000.

${ }^{91}$ Author's interview with a key informant in Bagan, Myanmar on August 30, 2017.

${ }^{92}$ Cheesman 2017; and Frydenlund 2017.

${ }_{93}$ Author's interview with a key informant in Yangon, Myanmar on August 22, 2017. 
of such framing is that the Rohingya entity is a modern construct: they are Chittagonian Bengalis who arrived and lived illegally in Myanmar as a result of British invasion. ${ }^{94}$ Indeed, the term Rohingya has become politically charged, and the government's consistent use of the word Bengal is not only weakening but erasing the traces and memories of the Rohingya identity in contemporary Myanmar. Rewriting the Rohingyan narrative rationalizes the employment of exclusionist strategies intended to secure the primacy of the Burman Buddhists by continuously rejecting the nationality and subjugating the identity of the othered Burman Muslims.

Here, we see how the securitization of the Rohingya Muslims in Rakhine has animated the construction and reconstruction of the realities informing the conditions and relations found within the principal nation-state. Traditional understandings about the self and the collective identity have been renegotiated, altering the Burman Buddhists' perceptions about the 'genuine' threats to their existence and security and their position as potential 'victims' of these threats. Put differently, it is precisely by articulating the issue of Rohingya Muslims as existential threats and assigning the majority Burman Buddhists as the primary targets of these threats, that such security realities are brought into being. Through this securitizing speech act, the dominant elite actors have been able to effectively present the Rohingyas as top state priority requiring 'extraordinary measures.' By a creating a condition in which the ethnoreligious minorities residing within the territories of the primary nation-state are portrayed as the threatening 'others', the direction of insecurity shifts from the outside to the inside. Indeed, the revised accounts and modified images which have resulted from the securitization of the Rohingyas are altering the Burmese people's perception and version of the reality.

Guided by the logic of particularistic ethnoreligious nationalism, the once familiar Rohingyas have been systematically debased, giving them a new identity as the abject-other - vile, filthy, and worthless. This provides the majority Burman Buddhists a psychological guarantee that they are indeed distinct from the Rohingyas, thereby reducing their own anxiety and insecurity about their own position. By projecting everything that they deem menacing and revolting about themselves onto the Muslim minorities in general, the powerful state and monastic elites have

${ }_{94}^{9}$ Author's interview with a key informant in Bagan, Myanmar on August 29, 2017. 
effectively sacralized themselves and the members of dominant ethnoreligious community on the back of the othered minorities. The successful dehumanization of the abject-other eases the legitimation of all emergency measures that are implemented to maintain the imaginary boundaries between the 'pure' Burman Buddhists and the 'dirty' Rohingya Muslims.

For instance, the ensuing 'clearance operations' which are being carried out by Myanmar's armed forces in the name of a Buddhist-centric Burmanization, have inexorably implicated the government to the ongoing charges of ethnic cleansing and state-sponsored genocide of the Rohingyas. ${ }^{95}$ Considering the rules being imposed on the Rohingyas - compulsory birth control, restrictions on marriage, systematic exclusion from positions of powers and employment in government institutions including police, army and judiciary - critics have argued that the Burmese state has been guilty of carrying out internal genocide. ${ }^{96}$ As Myanmar's nation-statehood evolves, the nature of Rohingyas' persona and status as a minority group has been routinely reinterpreted to prevent them from fitting inside, and fulfilling the standard identity and values imagined by the dominant Buddhist nationalists. Their relegation to the sidelines as non-Burmese Muslims led to their eventual expulsion from the land that they once shared with the Burman Buddhists for centuries, until they were demonized and turned into the 'abject-other.' By rendering them stateless, the Muslim Rohingyas have been effectively dispossessed of their right to have rights.

The Myanmar case shows how conceptions and narratives of a nation-state based on othering and exclusion are constructed and disseminated, enabling the dominant state and monastic elites to facilitate a certain degree of attitudinal conformity and compliance within the core ethnoreligious group. Their role as influential norm and discourse entrepreneurs allows them to consolidate and mobilize the loyalty and resources of the 'afflicted' majority against the familiar 'strangers'. Whereas key state leaders provide hard power to ethnoreligious elites supportive of their politics and policies to further legitimize their rule over the nation-state; influential ethnoreligious elites provide soft power to state leaders to secure the power and position of their ethnie and faith within that nation-state. This makes the constructed divisions

"Berlie 2008; Maung Zarni and Cowley 2014; and Kingston 2015.

${ }^{\circ}$ Green, MacManus and de la Cour Venning 2015; and Fortify Rights 2018. 
and imagined insecurities between the Burman Buddhists and the Rohingya Muslims look permanent and natural.

These dynamics generate a domestic security dilemma in which the continued dominance of the Burman Buddhists necessitates the relative weakness and insecurity of the Rohingya Muslims. Put differently, the persistence of a Buddhist-configured nation-state rests upon the suppression of an Islamic imagined community rooted in the ethnoreligious and nationalist substructures of the Rohingya Muslims. Notwithstanding the destructive impacts of such internal arrangement, the Myanmar case reveals how efforts to sustain the conceptual cohesion and material integrity of the overarching nation-state have been anchored on the existing power differentials and security imbalances between the majority and minority ethnoreligious groups.

\section{SACRALIZING THE ‘BURMAN BUDDHIST’ NATION-STATE}

With the successful cultivation of ethnoreligious nationalism, and effective securitization of the othered minorities, powerful elite players further entrench the primacy and status of the overarching nation-state by sacralizing the security superstructures underpinning the prevailing order and power relations within it. This process requires the insertion and reproduction of the majority group's ethnoreligious and nationalist substructures within and across the fundamental security superstructures of the nation-state. To this extent, national security has become a continuation of ethnoreligious nationalism by other means - an instrument of statecraft designed to consolidate and mobilize the power and resources of the 'sacred' insiders vis-à-vis the 'corrupt' outsiders.

In Myanmar, the promotion of Buddhist nationalism and support for the Citizenship Law have created an atmosphere of tyranny and hostility toward the minorities. While on paper, the Burmese government is resolutely secularist, nonetheless, it is expected to institutionalize and legitimize the protection of the 'sacred' Buddhist polity at the expense of the othered minorities. ${ }^{97}$ Reluctance to decisively address the 'Rohingya threat', for instance, could be interpreted as softness, if not, conspiracy on the part of the state..$^{98}$ Similarly, efforts to promote human rights

"Walton and Hayward 2014.

${ }^{\circledR}$ Author's interview with a key informant in Yangon, Myanmar on August 24, 2017. 
norms or investigate military abuses against the Rohingyas, might be viewed as a means of encouraging them and their religion. Even government declarations endorsing democratic pluralism to facilitate peaceful relations among ethnoreligious enclaves could be construed as an excuse to relinquish Buddhist political power and cultural status to an illegitimate minority.

Here, we see how national security interests are often subjectively formed and pursued via a political process that owes more to the logic of domestic politics as opposed to the logic of strategy. Far from being two sperate domains, security politics and ethnoreligious affairs in Myanmar are deeply intertwined. The country's pre-existing ethnic and religious cleavages continue to define the rules of membership and standards of behavior observed within and between its societies. Hence, when dealing with the 'threats' that contradict and challenge their constitution of being 'Burman Buddhists', the majority leaders and members tend not to be too rational with their approach. This implies that the state elites do not just mobilize ethnoreligious and nationalist substructures to justify their creation and implementation of security superstructures, their conduct of politics and the political mediums through which they operate are also infiltrated with nonrational, nonmaterial elements. Irrespective of whether they are tactically or substantively bound by ethnoreligious nationalism, harnessing its undertows have been useful for securing the primacy of the prevailing 'Burman Buddhist' nation-state, as well as maintaining their authority, influence, and power within the given order.

This helps explain the continuous proliferation of anti-Rohingya rhetoric being produced by certain groups of extremist Burman Buddhists. The most influential among them is the Association for the Protection of Race and Religion or more popularly known as the MaBaTha. ${ }^{99}$ Its leader, Ashin Wirathu, and dubbed the 'Face of Buddhist Terror', has admitted that these laws are meant to eradicate Muslim practices which he believes would bring Myanmar a future of Islamic tyranny and lead to the persecution of the native Burman Buddhists if left unchecked. ${ }^{100}$ Individuals and organizations that have tried to question the validity of their ideology and the soundness of their legislative proposals, have been accused of betraying the race and religion of the nation. ${ }^{101}$

\footnotetext{
" Nyi Nyi Kyaw 2015; Tharaphi Than 2015.

${ }^{100}$ Beech 2013.

${ }^{101}$ Lee 2016.
} 
Nevertheless, the decision of broad sections of the Burman population to overlook such interference in domestic politics has been crucial to the eventual passage of the Race and Religion Protection Laws in 2015. The legislative package consists of four separate parts: the Control of Population and Health Care Law (to prevent the number of the 'illegal Bengalis', meaning Rohingyas from increasing); the Religious Conversion Law (to prohibit forced conversion of Buddhist women to Islam); the Interfaith Marriage Law (to ensure the right of religious freedom of Buddhist women married to Muslim men to and their protection against sexual violence in marriage); and the Monogamy Law (to reduce the size of Muslim families particularly in the Rakhine region). ${ }^{102}$

As far as race and religious issues are concerned, the monkhood in Myanmar possesses greater credibility and legitimacy than both the government and its appointed religious authorities. ${ }^{103}$ In the eyes of the MaBaTha members, the lukewarm attempts being made by Aung Suu Kyi's National League for Democracy Party to placate ultranationalist Buddhists are only magnifying the government's perceived weakness and unwillingness to defend the 'true' Burman ethnicity and faith. ${ }^{104}$ They believe that because Buddhist teachings do not apply to them, a person's discriminatory behavior and cruel attitude toward these 'wrong believers' can still be right and moral if the intention is to defend the religion and race of the Burman Buddhists. ${ }^{105}$

Here, we see how dominant ethnoreligious elites are perceived as the ultimate guardians and prophets of national identity, giving their lectures and speeches greater currency over the more secular political treatises. Accordingly, the way that most Burman Buddhists understand the concepts of right or wrong and just or immoral vis-à-vis their relations with the Rohingya Muslims, is influenced by the ethnicized religious philosophies and traditions observed within their communities. This form of soft power helps elevate the leaders and sages of the dominant ethnoreligious group into sacred authority figures, giving them the capacity to influence the political actors responsible for the creation of state security superstructures.

Given the paramountcy of these belief systems to individual thought process and societal

${ }_{102}$ Frydenlund 2017; and van Klinken and Thazin Aung 2017.

${ }^{103}$ Author's interview with a key informant in Yangon, Myanmar on August 25, 2017.

${ }^{104}$ Author's interview with a key informant in Yangon, Myanmar on August 25, 2017.

${ }^{105}$ Author's key informant with a key informant in Bagan, Myanmar on August 30, 2017. 
consciousness, all issues believed to threaten their infallibility and sacredness are routinely securitized. Doing so has enabled the Burman Buddhists to secure and strengthen the foundations of their 'home' in which their 'pure identity' is anchored, providing them safety and protection from the 'threatening' Rohingya Muslims. Embedding Burman Buddhist nationalism when configuring national security sacralizes the security superstructures being built to shield this home. Meanwhile, criticisms and resistance toward these policy instruments and the actors responsible for them are deemed as sacrilegious rebellions against 'God' and its 'chosen people.'

The Myanmar case illustrates how the illusion of 'pure identity' combined with the myth of 'chosenness', have facilitated the adoption of 'just wars' designed to ethnically and religiously homogenize the Burmese nation-state. Due to the belief that sacred territories must be pure and exclusive, certain wars are carried out in order to expel the othered minorities accused of contaminating and compromising the purity and security of the home. Identifying and legitimizing the Burman Buddhists as the true 'chosen ones', therefore, becomes a highly crucial task on the part of powerful ethnoreligious elites. In the process of identifying and segregating the 'impostors' from the 'bona fide' Burman Buddhists, these 'just wars' have been put in motion to warrant the scapegoating of the Rohingyan minorities. This has resulted in the symbolic rejection and social expulsion of these ethnoreligious minorities into the zone of killing.

The idea is to ensure that Myanmar's political and cultural boundaries are perfectly aligned to resemble 'a congregation where members sing the same hymns, listen to the same gospel, and share the same emotion.' ${ }^{106}$ Whereas the cultivation of ethnoreligious nationalism and the securitization of othered minorities have provided the jus ad bellum for implementing these wars; the sacralization of security superstructures underpinning the primary nation-state has outlined the jus in bello for executing them. These continuing efforts to force-feed a Burman Buddhist conception and narrative of the nation-state have severely thwarted the formation of a national identity that is compelling enough to absorb and overcome conflicting cleavages in Myanmar. On the contrary, the distinctive Rohingyan ethnoreligious and linguacultural traits have turned them into convenient scapegoats for facilitating a chauvinistic process of nation-state

${ }^{106}$ Ignatieff 1993, 95. 
building that has resulted in their endemic persecution and the subjugation of their own imagined community.

\section{Conclusion}

The forceful resurgence of religious fundamentalism, ethnic factionalism, and nationalist impulses in the twenty-first century, are exposing the limits and weaknesses of scholarly works built around the modernization thesis and secularization logic. Given the multiple causes of material and nonmaterial layers of 'realities' that constitute the modern nation-states, as well as the complex ways in which these layers interact, the presumption that these units are unitary rational actors is both erroneous and constraining. To echo Stuart Kaufman, just as physicists recognize that the only way to describe complex systems is to take into account multiple physical forces, international relations theory must also accept that multiple causal logics typically operate at the same time. ${ }^{107}$ Guided by this philosophy, instead of rejecting the nonrational, nonmaterial cultural sources as archaic artefacts, I have developed and tested my framework to provide an explanation for why and how nation-states manage to persist by emphasizing the enduring relevance of religion and nationalism. By interlinking the concepts of security, nationalism, and religion, I have identified conceptual apparatuses which I have found crucial to understanding their continued survival, particularly in highly religious and ethnically divided locales, namely: ethnoreligious nationalism, securitized minorities, and sacralized security superstructures.

A major component of the framework is imbrication of the dominant religion and ethnic identity. This process is manifested through the cultivation of ethnoreligious nationalism (track 1) that bolsters and destroys existing identity distinctions between the ethnic members of the majoritarian faith and minority religions as deemed fit by the key state and religious elites. ${ }^{108}$ The purpose of this is to legitimize the development and implementation of a national security agenda that heavily favors the majority religion and its members' vision of a nation-state. The result is a bipolar mechanism that exploits inclusive institutions to co-opt the members of the dominant

${ }^{100}$ Kaufman 2019, 3.

"wee, Anderson 1983; Gellner and Breuilly 1983; Juergensmeyer 1993; Smith 1998; Hastings 1997; Friedland 2001; Hassner 2003; Kinnvall 2004; and Haynes 2016. 
group and fortify their nation-statehood; while imposing extractive institutions on the othered minorities to weaken and suppress their own versions and narratives of the nation-state. Both measures are intended to make nationhood consonant with statehood by aligning the 'official' conceptions and accounts of the nation and the state together, believing that this would create a more homogenous and, therefore, a more secure and stable nation-state.

The rise of ethnoreligious nationalism and its increasing currency over the construction and operation of the nation-state, paves the way for the securitization of the 'othered' minorities (track 2 of the framework) as 'existential threats' to the majoritarian faith by the dominant elites. ${ }^{109}$ This process justifies the calls for giving the hegemonic religion state-guaranteed protection because to defend the faith of the majority is to defend the national identity and territorial integrity of the nation-state. Accordingly, portraying minority religions and their members as existential threats becomes a necessity that must be constantly maintained and reproduced. One of the conditions that results from this is an internal security dilemma in which the security of the dominant group ultimately rests upon the relative insecurity and weakness of other minorities. Notwithstanding the disastrous impact of this type of domestic configuration vis-à-vis a culturally heterogenous space, nevertheless, in many highly religious and ethnically diverse societies, it is precisely these internal power imbalances which sustain the cohesion and integrity of the existing nation-state.

The securitization of the issue of ethnoreligious minorities further strengthens the already vast influence that the dominant elites hold over the creation and legitimation of state security superstructures (track 3 of the framework). ${ }^{110}$ On the one hand, security rhetoric and policies are crafted by powerful actors who are simultaneously exploiting and are being influenced by the dominant religion's doctrines and myths. On the other, the security strategies and institutions that these powerful players tend to adopt are also heavily biased in favor of the majoritarian faith's dogmas and norms. The overall national security plan, therefore, traditionally aligns with, and strengthens the core elements of the nation-state as imagined and conceived by the prevailing ethnoreligious group. Such a condition makes the current order that systematically marginalizes

109 See, Buzan, Wæver and de Wilde 1998; Laustsen and Wæver 2000; Balzacq 2010; and Hameiri Jones 2013.

${ }^{110}$ See, Horowitz 2009; Hassner 2003 and 2007; Norris and Inglehart 2011; and Haynes 2016. 
and neglects the ethnoreligious minorities seem natural, right, and just - further solidifying the claims being made by the most favored religious group about their role as guardians and symbols of national identity, and how their sacred institutions constitute the cornerstones of the principal nation-state.

Applying this three-track framework to Myanmar, I have demonstrated how ethnicized religion and nationalism remain central to the imagination of a nation-state; and why they are vital to the construction of both inclusive and extractive institutions intended to secure the consistency and integrity of this unit. Based on the insights I drew from my theoretical and empirical analyses, as well as the supporting evidences and findings I gathered from my fieldwork, the persistence of a nation-state is strongly attributable to the underlying material security superstructures which are both the outcomes and the drivers of intertwining nonrational, nonmaterial ethnoreligious and nationalist substructures. The consolidation of security interests, religious motives, and nationalist aspirations, as conceived and defined by the dominant elites and their respective ethnoreligious groups within specific territories, gives rise to a sequence of events - cultivation of ethnoreligious nationalism, securitization of the othered minorities, and sacralization of security superstructures - designed to secure and reinforce the formative and substantive elements of the principal nation-states at the expense of the imagined communities of other minorities.

Regardless of whether their functions are essentialist (primordialist) or constructivist (instrumentalist) in nature, the most important point to emphasize is that these ethnoreligious and nationalist cultures are vessels through which the structural power and institutional security (both inclusive and extractive) between the 'us' and the 'them' are recalibrated and rebalanced. Hence, far from being archaic, these nonrational, nonmaterial elements remain pivotal to the reimagination, renegotiation and, indeed, survival of modern nation-states not only in Southeast Asia but also (as the framework will predict) in some of the most religiously committed and ethnically divided regions across the world - from Africa and the Middle East, to South Asia and all the way to the Americas.

The findings underscore the importance of recognizing these nonrational, nonmaterial elements as legitimate constituents and instruments of realpolitik and, as such, must be given a 
seat at policymaking tables. Discounting their role and impact simply because they cannot be seen and measured is detrimental not only to security experts who continue to limit their focus on material, quantifiable ways of explaining domestic and international politics, but also to the policymakers they advise. Proper analysis has often been the casualty of extravagant dependence on modernization and secularization theses, resulting in profound misreading and miscalculation of political phenomena, trends, and societies in various parts of the world. The development and application of the framework presented here generates a thick qualitative description and analysis of the enduring relevance of religion and nationalism vis-à-vis the modern nation-states, which in turn, gives quantitative studies a more solid basis on which to draw and anchor their different models and variables.

\section{References}

Acemoglu, Daron and James Robinson. 2012. Why Nations Fail: The Origins of Power, Prosperity, and Poverty. New York: Crown Books.

Almond, Gabriel and James Smoot Coleman, eds. 2015. The Politics of the Developing Areas. New Jersey: Princeton University Press.

Anderson, Benedict. 1983. Imagined Communities: Reflections on the Origin and Spread of Nationalism. London: Verso Books.

Apter, David. 1965. The Politics of Modernization. Chicago: University of Chicago Press.

Armstrong, John. 1997. Religious Nationalism and Collective Violence. Nations and Nationalism 3 (4): 597-606.

Ashmore, Richard Lee Jussim and David Wilder, eds. 2001. Social Identity, Intergroup Conflict, and Conflict Reduction. New York: Oxford University Press.

Balzacq, Thierry, ed. 2010. Understanding Securitization Theory: How Security Problems Emerge and Dissolve: London: Routledge.

Barber, Benjamin. 1992. Jihad vs. McWorld. The Atlantic (March). Available at <https: / / www.theatlantic.com/magazine/ archive/1992/03/jihad-vs-mcworld/303882/>. Accessed 15 March 2019.

Baumann, Gerd. 1999. The Multicultural Riddle: Rethinking National, Ethnic and Religious Identities. New York: Routledge.

Beech, Hannah. 2013. The Face of Buddhist Terror. Time (July). Available at <http: / / content.time.com/time/magazine/article/0,9171,2146000,00.html>. Accessed on 28 March 2019.

Berlie, Jean. 2008. The Burmanization of Myanmar's Muslims. Bangkok: White Lotus Press.

Beyer, Peter. 1998. Globalizing Systems, Global Cultural Models and Religion (s). International Sociology, 13 (1): 79-94. 
Beyer, Peter and Lori Beaman eds. 2017. Religion, Globalization, and Culture. Leiden: Brill, 2007.

Bosco, Robert. 2014. Securing the Sacred: Religion, National Security, and the Western State. Ann Arbor: University of Michigan Press.

Beyer, Peter. 1998. Globalizing Systems, Global Cultural Models and Religion (s). International Sociology, 13 (1): 79-94.

Brubaker, Rogers. 2004. Ethnicity Without Groups. Boston: Harvard University Press.

Brubaker, Rogers. 2011. Religion and Nationalism: Four Approaches. Nations and Nationalism 18 (1): 2-20.

Buzan, Barry, Ole Wæver and Jaap De Wilde. 1998. Security: A New Framework for Analysis. Boulder: Lynne Rienner.

Cady, John. 1958. A History of Modern Burma. Ithaca: Cornell University Press.

Cheesman, Nick. 2017. How in Myanmar 'National Races' Came to Surpass Citizenship and Exclude Rohingya. Journal of Contemporary Asia, 47 (3): 461-483.

Croissant, Aurel and Philip Lorenz. 2018. Comparative Politics of Southeast Asia. Basel: Springer.

Davies, Matthew. 2012. The Perils of Incoherence: ASEAN, Myanmar and the Avoidable Failures of Human Rights Socialization. Contemporary Southeast Asia 34 (1): 1-22.

Deutsch, Karl. 1953. Nationalism and Social Communication: An Inquiry into the Foundations of Nationality. Massachusetts: MIT Press.

Eisenstadt, Shmuel. 2000. The Reconstruction of Religious Arenas in the Framework of Multiple Modernities. Millennium, 29(3): 591-611.

Elshtain, Jean ed. 1992. Just War Theory. New York: New York University Press.

Featherstone, Mike, ed. 1990. Global Culture: Nationalism, Globalization and Modernity. London: Sage.

Friedland, Roger. 2001. Religious Nationalism and the Problem of Collective Representation. Annual Review of Sociology 27 (1): 125-152.

Friedland, Roger. 2002. Money, Sex, and God: The Erotic Logic of Religious Nationalism. Sociological Theory 20 (3): 381-425.

Freidman, Thomas. 2005. The World Is Flat. New York: Farrar, Straus and Giroux.

Fortify Rights. 2018. Preparations for Genocide and Crimes Against Humanity Against Rohingya Muslims in Rakhine State, Myanmar. FRO (July). Available at

$<$ https: / / www.fortifyrights.org/downloads/Fortify_Rights_Long_Swords_July_2018.pdf $>$. Accessed on March 26, 2019.

Fox, Jonathan. 2003. Religion as an Overlooked Element of International Relations. International Studies Review 3 (3): 53-73.

Frydenlund, Iselin. 2017. Religious Liberty for Whom?: The Buddhist Politics of Religious Freedom during Myanmar's Transition to Democracy. Nordic Journal of Human Rights 35 (1): 55-73.

Fukuyama, Francis. 1992. The End of History and the Last Man. New York: Free Press.

Furnivall, John. 2014. Colonial Policy and Practice. New York: Cambridge University Press.

Gellner, Ernest and John Breuilly. 1983. Nations and Nationalism. Ithaca: Cornell University Press. 
Guibernau, Montserrat. 1997. Marx and Durkheim on Nationalism. In Rethinking Nationalism and Ethnicity: The Struggle for Meaning and Order in Europe, edited by Hans-Rudolf Wicker, 73-90. Oxford: Blommsbury.

Giddens, Anthony. 1987. The Nation-State and Violence. Berkeley: University of California Press.

Gravers, Mikael. 2015. Disorder as Order: The Ethno-Nationalist Struggle of the Karen in Burma/Myanmar. Journal of Burma Studies 19 (1): 27-78.

Gravers, Mikael. 2015. Anti-Muslim Buddhist Nationalism in Burma and Sri Lanka: Religious Violence and Globalized Imaginaries of Endangered Identities. Contemporary Buddhism 16 (1): 1-27.

Green, Penny, Thomas MacManus and Alicia de la Cour Venning. 2015. Countdown to Annihilation: Genocide in Myanmar. London: International State Crime Initiative.

Hadden, Jeffrey. 1987. Toward Desacralizing Secularization Theory. Social Forces 65 (3): 587-611.

Hall, John. 2000. Cultural Meanings and Cultural Structures in Historical Explanation. History and Theory 39 (3): 331-347.

Hameiri, Shahar and Lee Jones. 2013. The Politics and Governance of Non-Traditional Security. International Studies Quarterly 57 (3): 462-473.

Hassner, Ron. 2003. To Halve and to Hold: Conflicts Over Sacred Space and the Problem of Indivisibility. Security Studies 12 (4): 1-33.

Hassner, Ron. 2007. Islamic Just War Theory and the Challenge of Sacred Space in Iraq. Journal of International Affairs. 61 (1): 131-152.

Hastings, Adrian. 1997. The Construction of Nationhood: Ethnicity, Religion and Nationalism. New York: Cambridge University Press.

Haynes, Jeffrey. 2016. Religious Transnational Actors and Soft Power. London: Routledge.

Hechter, Michael. 2000. Containing Nationalism. New York: Oxford University Press.

Holton, Robert. 2011. Globalization and the Nation State. London: Macmillan International.

Horowitz, Michael. 2009. Long Time Going: Religion and the Duration of Crusading. International Security 34 (2): 162-193.

Hughey, Michael, ed. 1998. New Tribalisms: The Resurgence of Race and Ethnicity. London: Macmillan Press.

Human Rights Watch. 2000. Discrimination in Arakan. HRW (no date). Available at

<https: / / www.hrw.org/ reports/2000/burma/burm005-02.htm>. Accessed on 23 March 2019.

Huntington, Samuel. 1993. The Clash of Civilizations?. Foreign Affairs (June). Available at <https: / / www.foreignaffairs.com/articles/united-states/1993-06-01/clash-civilizations> / Accessed 15 March 2019.

Iannaccone, Laurence. 1995. Voodoo Economics? Reviewing the Rational Choice Approach to Religion. Journal for the Scientific Study of Religion, 34(1): 76-88.

Ignatieff, Michael. 1993. Blood and Belonging: Journeys into the New Nationalism. London: Vintage.

Imhof, Kurt. 1997. Nationalism and the Theory of Society. In In Rethinking Nationalism and Ethnicity: The Struggle for Meaning and Order in Europe, edited by Hans-Rudolf Wicker, 57-72. Oxford: Blommsbury. 
International Crisis Group. 2017. Buddhism and State Power in Myanmar. ICG (September). Available at <https: / / www.crisisgroup.org/asia / south-east-asia / myanmar / 290-buddhism-and-statepower-myanmar>. Accessed on 15. March 2019.

Institute for Comparative Survey Research. 2019. World Values Survey. ICSR (no date). Available at <http: / / www.worldvaluessurvey.org/WVSOnline.jsp>. Accessed March 1, 2019.

Johnston, Douglas and Cynthia Sampson, eds. 1995. Religion: The Missing Dimension of Statecraft. New York: Oxford University Press.

Juergensmeyer, Mark. 1993. The New Cold War?: Religious Nationalism Confronts the Secular State (Los Angeles: University of California Press.

Juergensmeyer, Mark. 1996. The Worldwide Rise of Religious Nationalism. Journal of International Affairs 50 (1): 1-20.

Karyotis, Georgios and Stratos Patrikios. 2010. Religion, Securitization and Anti-immigration Attitudes: The Case of Greece. Journal of Peace Research 47 (1): 43-57.

Kaufman, Stuart. War as Symbolic Politics. International Studies Quarterly. Online first (April 2019): 1-12, doi.org/10.1093/isq/sqz018.

Kautsky, John. 1972. The Political Consequences of Modernization. New York: Wiley.

Kingston, Lindsey. 2015. Protecting the World's Most Persecuted: The Responsibility to Protect and Burma's Rohingya Minority. The International Journal of Human Rights 19 (8): 1163-1175.

Kinley, David and Trevor Wilson. 2007. Engaging a Pariah: Human Rights Training in Burma/Myanmar. Human Rights Quarterly 29 (3): 368-402.

Kinnvall, Catarina. 2004. Globalization and Religious Nationalism: Self, Identity, and the Search for Ontological Security. Political Psychology 25 (5): 741-767.

Kristeva, Julia. 1991. Strangers to Ourselves. New York: Columbia University Press.

Khin Yi. 2000. 1998. Dobama Movement in Burma 1930-1938. Ithaca, Cornell University Press.

Laustsen, Carsten and Ole Wæver. 2000. In Defence of Religion: Sacred Referent Objects for Securitization. Millennium 29 (3): 705-739.

Lee, Ronan. 2016. The Dark Side of Liberalization: How Myanmar's Political and Media Freedoms are Being Used to Limit Muslim Rights. Islam and Christian-Muslim Relations 27 (2): 195-211.

Liow, Joseph. 2016. Religion and Nationalism in Southeast Asia. Cambridge: Cambridge University Press.

Lucius, Casey. 2012. Religion and the National Security Strategy. Journal of Church and State 55 (1): pp. 5070 .

Luttwak, Edward. 2001. Strategy: The Logic of War and Peace. Cambridge: Harvard University.

Marsden, Lee. 2019. Religion and International Security. Cambridge: Polity Press.

Matthews, Bruce. 1993. Buddhism Under a Military Regime. Asian Survey 33 (4): 408-423.

Marty, Martin and Scott Appleby, eds. Accounting for Fundamentalisms: The Dynamic Character of Movements. Chicago: University of Chicago Press. 
Mendelson, Michael. 1975. Sangha and the State in Burma. A Study of Monastic Sectarianism and Leadership. Ithaca: Cornell University Press.

Miyoshi, Masao. 1993. A Borderless World? From Colonialism to Transnationalism and the Decline of the Nation-State. Critical Inquiry 19 (4): 726-751.

Nemoto, Kei. 2000. The Concepts of Dobama and Thudo-Bama in Burmese Nationalism, 1930-1948. Journal of Burma Studies 5 (1): 1-16.

Norris, Pippa and Ronald Inglehart. 2011. Sacred and Secular: Religion and Politics Worldwide. New York: Cambridge University Press.

Nyi Nyi Kyaw. 2015. Alienation, Discrimination, and Securitization: Legal Personhood and Cultural Personhood of Muslims in Myanmar. The Review of Faith and International Affairs 3 (4): 50-59.

Nyi Nyi Kyaw. 2016. Islamophobia in Buddhist Myanmar: The 969 Movement and Anti-Muslim Violence. In Islam and the State in Myanmar: Muslim-Buddhist Relations and the Politics of Belonging, edited by Melissa Crouch, 183-210. Oxford: Oxford University Press.

Olson, Mancur. 2009. The Logic of Collective Action. Massachusetts: Harvard University Press.

Ohmae, Kenichi. 1995. The End of the Nation State: The Rise of Regional Economies. New York: The Free Press.

Pecora, Vincent. 2006. Secularization and Cultural Criticism: Religion, Nation, and Modernity. Chicago: University of Chicago Press.

Petito, Fabio and Pavlos Hatzopoulos. 2003. Religion in International Relations: The Return from Exile. New York: Palgrave Macmillan.

Pew Research Center. 2018. Religious Commitment by Country and Age. PRC (June). Available at <https: / / www.pewforum.org/2018/06/13/how-religious-commitment-varies-by-country-amongpeople-of-all-ages/>. Accessed 1 March 2019.

Pew Research Center. 2017. The Changing Global Religious Landscape. PRC (April). Available at $<$ https: / / www.pewforum.org/2017/04/05/the-changing-global-religious-landscape/>. Accessed 1 March 2019.

Philpott, Daniel. 2007. Explaining the Political Ambivalence of Religion. American Political Science Review. 101 (3): 505-525.

Przeworski, Adam and Fernando Limongi. 1997. Modernization: Theories and Facts." World Politics 49 (2): 155-183.

Robins, Robert and Jerrold Post, Political Paranoia: The Psychopolitics of Hatred. New Haven: Yale University Press.

Rubin, Barry. 1994. Religion and International Affairs. In Religion, the Missing Dimension of Statecraft edited by Douglas Johnston and Cynthia Sampson, 20-36. Oxford: Oxford University Press.

Sahliyeh, Emile, ed. 1990. Religious Resurgence and Politics in the Contemporary World. New York: SUNY Press.

Schissler, Matt, Matthew Walton and Phyu Phyu Thi. 2017. Reconciling Contradictions: Buddhist-Muslim Violence, Narrative Making and Memory in Myanmar. Journal of Contemporary Asia 47(3): 376-395. 
Seiple, Robert and Dennis Hoover, eds. 2004. Religion and Security: The New Nexus in International Relations Lanham: Rowman and Littlefield.

Smith, Anthony. 1983. Nationalism and Classical Social Theory. The British Journal of Sociology, 34(1): 1938.

Smith, Anthony. 1998. Nationalism and Modernism. London: Routledge.

Smith, Anthony. 2003. Chosen Peoples: Sacred Sources of National Identity. Oxford: Oxford University Press.

Smith, Donald. 1965. Religion and Politics in Burma. New Jersey: Princeton University Press.

Smith, Donald. 1971. Religion, Politics, and Social Change in the Third World: A sourcebook. New York: Free Press.

Snyder, Jack, ed. Religion and International Relations Theory. New York: Columbia University Press.

Stiglitz, Joseph. 2002. Globalization and its Discontents. New York: Norton.

Spohn, Willfried. 2003. Multiple Modernity, Nationalism and Religion: A Global Perspective. Current Sociology, 51 (3-4): 265-286.

Stark, Rodney. 1999. Secularization, R.I.P. Sociology of Religion, 60(3): 249-273.

Stavenhagen, Rodolfo. 1996. Ethnic Conflicts and the Nation-State. London: Macmillan Press.

Steinmetz, George, ed. 2018. State/Culture: State-Formation After the Cultural Turn. Ithaca: Cornell University Press.

Stevens, David. 1997. Nationalism as Religion. Studies: An Irish Quarterly Review 86 (343): 248-258.

Stritzel, Holger. 2007. Towards a Theory of Securitization: Copenhagen and Beyond. European Journal of International Relations 13 (3): 357-383.

Tambiah, Stanley. 1996. Leveling Crowds: Ethnonationalist Conflicts and Collective Violence in South Asia. Berkeley: University of California Press.

Tharaphi Than. 2015. Nationalism, Religion, and Violence: Old and New Wunthanu Movements in Myanmar. The Review of Faith and International Affairs 13 (4): 12-24.

Thomas, Scott. 2000. Taking Religious and Cultural Pluralism Seriously: The Global Resurgence of Religion and the Transformation of International Society. Millennium, 29(3): 815-841.

Thompson, Andrew and Ralph Fevre. 2001. The National Question: Sociological Reflections on Nation and Nationalism. Nations and Nationalism, 7(3): 297-315.

Tilly, Charles. 1996. The State of Nationalism. Critical Review, 10(2): 299-306.

Tomlinson, John. 1999. Globalization and Culture. Chicago: University of Chicago Press.

van Der Veer, Peter and Hartmut Lehmann, eds. 1999. Nation and Religion: Perspectives on Europe and Asia New Jersey: Princeton University Press.

van Klinken, Gerry and Su Mon Thazin Aung. 2017. The Contentious Politics of Anti-Muslim Scapegoating in Myanmar. Journal of Contemporary Asia 47 (3): 353-375.

Volkan, Vamik. 1998. Bloodlines: From Ethnic Pride to Ethnic Terrorism. New York: Basic Books. 
Walton, Matthew and Susan Hayward. 2014. Contesting Buddhist Narratives: Democratization, Nationalism, and Communal Violence in Myanmar. Honolulu: East-West Center.

Wæver, Ole. 1995. Securitization and Desecuritization. In On Security, edited by Ronnie Lipschutz, $46-86$. New York: Columbia University Press.

Wentz, Richard. 1987. Why People Do Bad Things in the Name of Religion. Macon: Mercer University Press.

Wimmer, Andreas and Nina Schiller. 2002. Methodological Nationalism and Beyond: Nation-State Building, Migration and the Social Sciences. Global Networks, 2(4 ): 301-334.

Zarni, Maung and Alice Cowley. 2014. The Slow-Burning Genocide of Myanmar's Rohingya. Pacific Rim Law and Policy Journal 23 (3): 683-754.

Zubrzycki, Geneviève, ed. National Matters: Materiality, Culture, and Nationalism. Stanford: Stanford University Press. 